\title{
Handover between anaesthetists and post-anaesthetic care unit nursing staff using ISBAR principles: A quality improvement study
}

Follow this and additional works at: https://www.journal.acorn.org.au/jpn

Part of the Health Services Administration Commons, Health Services Research Commons, Perioperative, Operating Room and Surgical Nursing Commons, and the Surgery Commons

\section{(c) (1)}

This work is licensed under a Creative Commons Attribution 4.0 License.

\section{Recommended Citation}

Kitney, Patricia; Tam, Raymond; Bennett, Paul; Buttigieg, Dianne; Bramley, David; and Wang, Wei (2016) "Handover between anaesthetists and post-anaesthetic care unit nursing staff using ISBAR principles: A quality improvement study," Journal of Perioperative Nursing: Vol. 29 : Iss. 1 , Article 2.

Available at: https://doi.org/10.26550/2209-1092.1001

https://www.journal.acorn.org.au/jpn/vol29/iss1/2

This Article is brought to you for free and open access by Journal of Perioperative Nursing. It has been accepted for inclusion in Journal of Perioperative Nursing by an authorized editor of Journal of Perioperative Nursing. 


\section{Authors}

Patricia Kitney

RN, BAppSc-Nsg, DAppSc-Nsg Ed, MEd

(Research), GradCert LdrshipEdTrng,

GradCertPeriop

Western Health, Sunshine, Vic

Raymond Tam

MBBS FANZCA

Western Health, Sunshine, Vic

Paul Bennett

RN BN GradCertSc (App Stats) MHSM PhD

Deakin University, Geelong, Victoria,

Western Health - Nursing Research

Centre, Sunshine, Vic

Dianne Buttigieg

RN, BHSc (Nursing), Grad Cert Periop Nsg, DipMgt

Western Health, Sunshine, Vic

David Bramley

MBBS MPH FANZCA

Western Health, Sunshine, Vic

Wei Wang

Msc (Stats) GdipSci (Stats) MD PhD

Deakin University, Geelong, Vic

\section{Corresponding author}

Patricia Kitney

Clinical Nurse Educator - Perioperative

Services

Western Health, Gordon Street, Footscray

VIC 3011

Tel. 0383450506

patricia.kitney@wh.org.au

\section{Handover between anaesthetists and post-anaesthetic care unit nursing staff using ISBAR principles: A quality improvement study}

\author{
Abstract \\ A structured approach to communication between health care \\ professionals contains introduction/identification; situation; \\ background; assessment and request/recommendation (ISBAR). \\ ISBAR was introduced into the post-anaesthetic care unit (PACU) \\ of a large Victorian health service in 2013. The aim of this study \\ was to measure the effect of an education program on ISBAR \\ compliance.
}

Method: A pre/post-test design using a 14-item audit tool was used to measure compliance to ISBAR before and after an education intervention in two acute hospitals in Melbourne, Victoria. The intervention consisted of one 30-minute education session to anaesthetists, and two 30-minute education sessions to PACU nurses, combined with visual cues using ISBAR wall posters.

Results: In Hospital A, significant improvement from pre- to post-audit was found in the items of cardiovascular assessment $(x 2(1)=4.06, p<.05)$, respiratory assessment $(X 2(1)=12.85, p<.01)$, analgesia assessment and actions (Fisher's exact test $p<.05)$ and responsibility + referral $(x 2(1)=4.44$, $p<.05)$. For Hospital $B$ significant improvement was found in communication difficulties $(X 2(2)=13.55, p<.01)$ and significant decreased performance was found in respiratory assessment $(x 2(1)=8.98, p<.01)$ and responsibility + referral $(X 2(1)=13.26, p<.01)$.

Implication for practice: The results from this study cohort suggest an augmented education program may produce mixed results for ISBAR compliance. More than education and visual tools may be required to improve PACU ISBAR compliance.

\section{Keywords}

Handover, anaesthetist, post-anaesthetic care, post-anaesthetic nurse. 


\section{Background}

In 2012 the Australian Commission on Safety and Quality in Healthcare (ACSQHC) identified clinical handover as a key standard in the national quality and safety framework¹. With over seven million clinical handovers occurring annually in Australian hospitals, it was concerning that global handover processes have been highly variable and unreliable, and associated with patient risk and patient safety ${ }^{2}$. A recent review of 31 postoperative handover primary research studies confirmed the positive association between handovers and adverse events and recommended the standardisation of handover processes ${ }^{3}$. Standardisation of clinical handover is likely to improve the safety of patient care as critical information is more likely to be transferred and acted upon'.

In the perioperative environment surgeons, scrub nurses, anaesthetists, anaesthetic nurses and scout nurses are all involved in the care of the patient during a surgical procedure. Each team member is accountable for the information they transfer from one part of the patient journey to the next; however, in Australia, it is most commonly the anaesthetist who performs the post-operative handover ${ }^{4}$. The post-operative handover consists of the transfer of information of the patient's state and care by the anaesthetist to the post-anaesthetic care unit (PACU) staff with appropriate briefing on relevant aspects of the surgery and anaesthetic technique ${ }^{5}$.

ISBAR is a structured approach to communication between health care providers. ISBAR refers to: Introduction/Identification; Situation; Background; Assessment; and Request/Recommendation ${ }^{6}$. The introduction of ISBAR to Western Health, a large metropolitan health service in Melbourne, Victoria, was undertaken to provide a standardised organisation-wide approach?. The introduction of ISBAR identified issues of non-compliance, resulting in an education strategy being

\begin{tabular}{|l|l|}
\hline Identification & $\begin{array}{l}\text { Patient } \\
\text { Staff members }\end{array}$ \\
\hline Situation & $\begin{array}{l}\text { Procedure } \\
\text { Anaesthetic type }\end{array}$ \\
\hline Background & $\begin{array}{l}\text { Allergies } \\
\text { Co-morbidities } \\
\text { Communication difficulties (including non-English } \\
\text { speaking) }\end{array}$ \\
\hline $\begin{array}{l}\text { Assessment } \\
\text { \& Actions }\end{array}$ & $\begin{array}{l}\text { Intra-operative issues: } \\
\text { surgery and anaesthesia } \\
\text { Current issues: } \\
\text { cardiovascular observations, limits, therapy } \\
\text { respiratory observations, limits, therapy } \\
\text { \& analgesia interventions to date, orders } \\
\text { \& Referral }\end{array}$ \\
\hline $\begin{array}{l}\text { Name and contact details } \\
\text { ICU/HDU/ward/discharge home }\end{array}$ \\
\hline
\end{tabular}

Figure 1: ISBAR cue card

implemented. The aim of the quality improvement project reported here was to measure the effect the education program had on ISBAR compliance.

\section{Methods}

\section{Design}

A pre/post-test design using audit tools to measure compliance before and after a quality improvement intervention.

\section{Sample}

A convenience sample of anaesthetists were observed over a one-week period in two PACU units from two participating hospitals within the same health service. Handovers were performed by anaesthetists providing a clinical handover of their patients to PACU nursing staff were included in the audit. There were no data in the literature to guide detailed sample size calculations for comparison of before and after compliance with the ISBAR handover tool in PACU. Assuming normally distributed population data in the independent samples, a proposed sample size of 100 observations in each group would give $83 \%$ power to detect a difference in proportion of handover compliance from $50 \%$ to $70 \%$ at a significance level of 0.05 in a posthoc analysis of entire cohort. An historical case load suggested that this would result in a sample of approximately 200 events (clinical handovers).

\section{Intervention}

The intervention consisted of two strategies. Firstly, in-service education session to anaesthetists and PACU nurses on current handover performance was undertaken. The education sessions were mainly of a didactic nature, presenting evidence supporting the introduction 
of structured clinical handover. The model of ISBAR handover was presented and reinforced. Secondly, ISBAR poster-sized cue cards (Figure 1) were fixed to the walls of all PACU patient bays.

\section{Tool}

The audit tool was developed measuring the adherence to ISBAR principles during the handover from anaesthetist to PACU nurses (Figure 2). This was designed to encompass guidelines from the Australian and New Zealand College of Anaesthetists (ANZCA) and the health care organisation. To assist with face and content validity the tool was disseminated to expert clinicians where minor modifications were made. The tool was then piloted before the study where further minor modifications were undertaken.

\section{Data collection}

The pre-audit was undertaken immediately following the introduction of ISBAR. The education and poster strategy was implemented in the succeeding two weeks immediately following the audit. The post-audit was undertaken four months after the education and poster strategy. The audit tool (Figure 2) was completed by Sunshine and Footscray PACU nursing staff during the clinical handover by the anaesthetist once the patient had been connected to monitoring equipment and the patient was deemed stable by the PACU nurse. The audit tool was piloted in 10 handovers by two PACU nurse educators and found to be practical, timely and demonstrated high inter-rater agreement. Audits were undertaken by PACU nurses who had been trained to complete the audits during the two education sessions. Completed audits were placed into a secure box, which were collected from the box at the end of the oneweek period by the project team leader (PK).

\section{Ethics}

Quality assurance was reviewed by the Western Health Low Risk Research and Ethics Panel. Approval was granted on 13 October 2014. Low-

\begin{tabular}{|c|c|c|c|c|c|}
\hline I & Identification & Patient name & Yes & No & $N / A$ \\
\hline \multirow[t]{2}{*}{ S } & \multirow[t]{2}{*}{ Situation } & Procedure & & & \\
\hline & & Anaesthetic type & & & \\
\hline \multirow[t]{3}{*}{ B } & \multirow[t]{3}{*}{ Background } & Allergies & & & \\
\hline & & Co-morbidities & & & \\
\hline & & Communication difficulties (including NESB) & & & \\
\hline \multirow[t]{7}{*}{ A } & \multirow[t]{7}{*}{$\begin{array}{l}\text { Assessment \& } \\
\text { Actions }\end{array}$} & Intra-operative issues: surgery and anaesthesia & & & \\
\hline & & Current issues: & & & \\
\hline & & $\begin{array}{l}\text { Cardiovascular: observations, acceptable limits, therapy (including } \\
\text { IV fluids and interventions) }\end{array}$ & & & \\
\hline & & Respiratory: observations, acceptable limits, therapy (includes $\mathrm{O}_{2}$ ) & & & \\
\hline & & Analgesia: interventions to date, ongoing therapy & & & \\
\hline & & $\begin{array}{l}\text { Additional needs: e.g. Antiemetics, X-ray, biochemistry/ } \\
\text { haematology/BSL }\end{array}$ & & & \\
\hline & & Other comments & & & \\
\hline \multirow[t]{2}{*}{$\mathrm{R}$} & \multirow[t]{2}{*}{$\begin{array}{l}\text { Responsibility \& } \\
\text { Referral }\end{array}$} & Name and contact details & & & \\
\hline & & ICU/HDU/ward/discharge home & & & \\
\hline & & TOTAL SCORE & $/ 14$ & & \\
\hline \multicolumn{6}{|c|}{$\begin{array}{l}\text { Instructions to PACU nursing staff: } \\
\text { Maximum possible score = } 14 \\
\text { Each 'yes' response scores a 1; Each 'no' response or 'N/A' response scores a } 0\end{array}$} \\
\hline
\end{tabular}

Figure 2: ISBAR audit tool 
risk human research QA Reference Number: QA2014.94. Participants were non-identifiable as no identifying demographics were recorded.

\section{Outcome measures}

The outcome measures were differences in compliance between pre- and post-audit for all 14 audit tool items. These items recorded the identification of patient name, procedure, anaesthetic type, allergies, co-morbidities, communication difficulties, surgery and anaesthesia intraoperative issues, cardiovascular observations, respiratory observations, analgesia, additional needs, referral name and contact details, and likely transfer destination.

\section{Data analysis}

Crosstabs was used to examine the categorical nature of the data in determining whether there was a significant difference between the pre-audit (audit 1) and the postaudit (audit 2) across the 13 items of interest. The analysis was performed separately on two separate hospital sites (Hospital A and Hospital B). Pearson's chi-square statistics were reported. In addition, Fisher's exact tests were also reported for the items that the numbers were less than 5 in each cell.

\section{Results}

Table 1 shows the percentages and test results of crosstabs of the 283 handovers from the two hospital PACUs (Hospital A, $n=148$, Hospital B, n=135). In Hospital A, significant differences were found between audit 1 and audit 2 for the items of Assessment er Actions: Cardiovascular: observations, acceptable limits, therapy (including IV fluids $e$ interventions) $\left(x^{2}(1)=\right.$ 4.06, $p$ <.05); Assessment e Actions: Respiratory: observations, acceptable limits, therapy (includes 02) $\left(x^{2}(1)=\right.$
12.85, $p<.01)$; Assessment e Actions: Analgesia: interventions to date, ongoing therapy (Fisher's exact test $p$ $<$.05); and Responsibility er Referral: ICU/HDU/ward/discharge home ( $X^{2}(1)$ $=4.44, p<.05$ ).

For Hospital B, three items showed significant differences including Background: Communication difficulties (including NESB) $\left(X^{2}(2)=\right.$ 13.55, $p<.01$ ); Assessment er Actions: Respiratory: observations, acceptable limits, therapy (includes 02) $\left(X^{2}(1)=\right.$ 8.98, $p<.01$ ); and Responsibility e Referral: ICU/HDU/ward/discharge home $\left(X^{2}(1)=13.26, p<.01\right)$.

\section{Discussion}

The major findings from this audit demonstrate that education augmented with ISBAR posters can be associated with both an improvement but also decreased compliance of ISBAR principles. There were no audit elements where both hospitals improved significantly. In the higher acuity hospital (Hospital A) improvements were seen in the reporting of respiratory and cardiovascular observations, analgesia concerns and referral, whereas in Hospital B improvements were only noted in reporting communication difficulties. Improvements in Hospital A may have been associated with the increased acuity of patients occurring at this hospital. Hospital B's broader cultural profile may have had an influence on the attention to communication challenges during these handovers.

Decreased compliance in Hospital $B$ in the areas of respiratory observation and referral could not be explained. The contrast between this declining compliance and the improvement in these areas in Hospital A suggests that there is more influence on ISBAR compliance than simply an educational strategy augmented by cue cards. The importance of leadership and culture on the quality implementation of structured communication has been identified as vital ${ }^{2}$ and this may have had an influence on our results. In saying this, additional change strategies to supplement an education strategy may improve ISBAR compliance.

The PACU environment can be a stressful area and standardised care can improve patient care ${ }^{8}$. Handover failures are common and can lead to diagnostic and therapeutic delays ${ }^{3}$. Poor handover can also lead to wasted resources ${ }^{6}$. The breakdown in the transfer of information has been identified as one of the most important contributing factors in serious adverse events and is a major preventable cause of patient harm. Given the complexities of communication in health services and the mixed results from this study, more complex communication training 9 may augment standardised structured handover practices such as ISBAR.

ISBAR is an example of standardising a common process, handover, to facilitate a comprehensive transfer of patient information, assessment, progress and future state. Our study has demonstrated some success in improving this standardisation, with the ultimate goal of standardising and improving patient care processes.

\section{Strengths and limitations}

The major strength of this study was that it was undertaken in a practice environment in two large teaching hospitals within the one health service. In saying this, factors influencing ISBAR compliance, such as PACU leadership and management culture, were not objectively measured. ISBAR was the designated hospital organisations' handover 


\begin{tabular}{|c|c|c|c|c|c|c|c|c|}
\hline \multirow[b]{2}{*}{ Item } & \multicolumn{4}{|c|}{ Hospital A } & \multicolumn{4}{|c|}{ Hospital B } \\
\hline & $\begin{array}{l}\text { Audit } \\
1 \\
\text { Yes }\end{array}$ & $\begin{array}{c}\text { Audit } \\
2\end{array}$ & $\begin{array}{l}\text { Pearson } \\
\text { Chi-square } \\
\mathrm{p} \text { (2-sided) }\end{array}$ & $\begin{array}{l}\text { Fisher's } \\
\text { Exact Test } \\
\mathrm{p} \text { (2-sided) }\end{array}$ & $\begin{array}{c}\text { Audit } \\
1\end{array}$ & $\begin{array}{l}\text { Audit } \\
2 \\
(\%)\end{array}$ & $\begin{array}{l}\text { Pearson } \\
\text { Chi-square } \\
\text { p (2-sided) }\end{array}$ & $\begin{array}{l}\text { Fisher's } \\
\text { Exact Test } \\
\text { p (2-sided) }\end{array}$ \\
\hline 1. Identification: Patient name & 79.8 & 91.8 & & .10 & 79.8 & 91.8 & & .10 \\
\hline 2. Situation: Procedure & 99.0 & 100 & & 1.00 & 100 & 98.0 & & .37 \\
\hline 3. Situation: Anaesthetic type & 94.9 & 87.8 & & .18 & 94.1 & 100 & & .16 \\
\hline 4. Background: Allergies & 59.4 & 67.3 & .35 & & 65.5 & 78 & .13 & \\
\hline 5. Background: Co-morbidities & 80.6 & 91.8 & & .09 & 89.2 & 90.0 & & 1.00 \\
\hline $\begin{array}{l}\text { 6. Background: } \\
\text { Communication difficulties } \\
\text { (including NESB)* }\end{array}$ & 27.6 & 22.4 & .07 & & 30.6 & 44.0 & .00 & \\
\hline $\begin{array}{l}\text { 7. Assessment \& Actions: } \\
\text { Intra-operative issues: } \\
\text { surgery and anaesthesia* }\end{array}$ & 69.1 & 50.0 & .06 & & 70.4 & 80.9 & .42 & \\
\hline $\begin{array}{l}\text { 8. Assessment \& Actions: } \\
\text { Cardiovascular: } \\
\text { observations, acceptable } \\
\text { limits, therapy (including IV } \\
\text { fluids and interventions) }\end{array}$ & 65.7 & 81.6 & .04 & & 83.5 & 82.0 & .82 & \\
\hline $\begin{array}{l}\text { 9. Assessment \& Actions: } \\
\text { Respiratory: observations, } \\
\text { acceptable limits, therapy } \\
\text { (includes } \mathrm{O}_{2} \text { ) }\end{array}$ & 53.5 & 83.7 & .00 & & 81.2 & 57.1 & .00 & \\
\hline $\begin{array}{l}\text { 10. Assessment \& Actions: } \\
\text { Analgesia: interventions to } \\
\text { date, ongoing therapy }\end{array}$ & 80.8 & 93.9 & & $.05(.048)$ & 96.5 & 93.9 & & .67 \\
\hline $\begin{array}{l}\text { 11. Assessment \& Actions: } \\
\text { Additional needs: e.g. Anti- } \\
\text { emetic, X-ray, biochemistry/ } \\
\text { haematology/BSL* }\end{array}$ & 71.1 & 79.6 & .27 & & 67.1 & 78.0 & .18 & \\
\hline $\begin{array}{l}\text { 12. Responsibility \& Referral: } \\
\text { Name and contact details }\end{array}$ & 51.1 & 63.3 & .16 & & 71.4 & 60.4 & .19 & \\
\hline $\begin{array}{l}\text { 13. Responsibility \& Referral: } \\
\text { ICU/HDU/ward/discharge } \\
\text { home }\end{array}$ & 53.2 & 71.4 & .04 & & 76.2 & 44.9 & .00 & \\
\hline
\end{tabular}

*Item response options comprising three categories

Table 1: Comparison between audit 1 and audit 2 for Hospital A ( $n=148)$ and Hospital $B(n=135)$ 
policy. Alternative common iterations such as ISOBAR and SBAR were not assessed. This was a pre/ post-test audit design and thus our findings should not be generalised to other PACU contexts.

\section{Conclusion}

This study has shown ISBAR compliance in handover between anaesthetist and PACU nursing staff can be improved through education augmented with posters. However, significant elements of decreased compliance have also been observed. various contextual factors are likely to affect ISBAR compliance and should be considered when employing strategies to improve handover standardisation.

\section{References}

1. National Safety and Quality Health Service Standards: Australian Commission on Safety and Quality in Health Care - Standard 6: Clinical Handover - Safety and Quality Improvement Guide, 2012. Canberra: Australian Government.

2. Botti M, Bucknall T, Cameron P, Johnstone MJ, Redley B, Evans S \& Jeffcott S (2009). Examining communication and team performance during clinical handover in a complex environment: the private sector post anaesthetic care unit. Medical Journal of Australia, Vol. 190, No. 11, S157-160.

3. Segall $N$, Bonifacio AS, Schroeder RA, Barbeito A, Rogers D, Thornlow DK, ... \& Mark JB (2012). Can we make postoperative patient handovers safer? A systematic review of the literature. Anesthesia \& Analgesia, Vol. 115, No. 1, pp. 102-115.

4. Anumakonda V, Doijode S \& Bhaskaran $S$ (2011). A prospective audit of multidisciplinary handover (MDHO) of responsibility for patients in the post anaesthetic care unit in a District General Hospital (DGH): Patient safety perceptive.
European Journal of Anaesthesiology, Vol. 28, Suppl. 48, p. 215.

5. Nagdeve N \& Kada VK (2011). Quality of handover of patients to the postanaesthetic care unit staff: 17AP1-2. European Journal of Anaesthesiology, Vol. 28, p. 214.

6. Australian Commission on Safety and Quality in Healthcare: OSSIE Guide to Clinical Handover Improvement 2012. www. safetyandquality.gov.au/wp-content/ uploads/2012/01/ossie. pdf Retrieved 10 July 2015.

7. Western Health (2014). Clinical Handover. Policy code P-CC5.2 inside.wh.org.au/ policies-procedures-forms/WHDocuments/ Clinical. Handover.docx Retrieved 10 July 2015.

8. Gill SD, Hughes A, McCall-White M, Pascoe H (2014). Clinical Handover: An Audit from Australia. AMJ, Vol. 7, No. 9, pp. 363-371.

9. Watson BM, Manias E, Geddes F, Della P \& Jones D (2015). An analysis of clinical handover miscommunication using a language and social psychology approach. Journal of Language and Social Psychology, Online before print May 14, DOI: $20150261927 X 15586200$. 